\title{
UNIVERSITY OBJECTIVES AND SOCIOECONOMIC RESULTS. A MULTICRITERIA MEASURING OF ALIGNMENT
}

Félix Antonio Cortés-Aldana ${ }^{\mathrm{a}}$, Mónica García-Melón ${ }^{\mathrm{b} *}$, Ignacio Fernández-de-Lucio ${ }^{\mathrm{b}}$, Pablo Aragonés-Beltrán ${ }^{\mathrm{b}}$, Rocío Poveda-Bautista ${ }^{\mathrm{b}}$

\author{
${ }^{a}$ Departamento Ingeniería de Sistemas e Industrial. Facultad de Ingeniería. Universidad \\ Nacional de Colombia. Ciudad Universitaria - Bogotá D.C.- Colombia. Avenida Carrera \\ $30 \mathrm{~N}^{\circ} 45-03$ \\ ${ }^{\mathrm{b}}$ Departamento de Proyectos de Ingeniería, Universidad Politécnica de Valencia, \\ Camino Vera s/n, 46071 Valencia, Spain \\ * Corresponding author. Tel.: +34 9638798 60; Fax: +34 963879869 . \\ mgarciam@dpi.upv.es (Mónica García-Melón)
}

\begin{abstract}
Universities develop technology transfer mechanisms as the tools required to undertake missions committed to the socioeconomic environment. In this work a new proposal to measure the extent to which the goals or strategic objectives of a university are aligned with the results obtained through its technology transfer mechanisms with the local community is presented. This will enable to perform a diagnosis, by comparing the situation sought by the University Management team (expected case) with the actual one that derives from the application of the plans that implement the technology transfer mechanisms (real case). To achieve this, two different Multicriteria Decision Analysis techniques e.g. Analytic Network Process (ANP) and Analytic Hierarchy Process (AHP) will be used. Both the methodology and the MCDA techniques proposed need to be explained and clarified to the different experts who collaborate in the study, hence the facilitating process, key to the whole procedure, will be analysed in detail.

The model proposed in this study is applied to analyse the case of the National University of Colombia - Bogotá Campus. Findings show that the following questions can be answered: (i) How much importance is granted by the University Management to the objectives of the University? (ii) To what extent are the objectives of the university fulfilled by the technology transfer mechanisms to the socioeconomic environment? (iii)
\end{abstract}


Are the objectives of the university aligned with the results achieved through the technology transfer mechanisms?

Keywords: Multiple criteria analysis, Analytic Network Process (ANP), Analytic Hierarchy Process (AHP), relation between university and socioeconomic environment.

\section{Introduction}

The university, as an institution, came into being in the $12^{\text {th }}$ century with the educational mission of transmitting knowledge from teachers to pupils. Since then it has evolved from its ivory tower (that is, institutions where scientific knowledge is deposited and which are isolated from society) to a new position within the socioeconomic environment, where it acts as an agent to further national and regional development (Geuna, 1998).

According to Etzkowitz et al. (2000, 2003), the development of universities over the years has led them to undertake missions that are increasingly more committed to the society around them:

1. Teaching: conservation and dissemination of knowledge (from their early days until the late $19^{\text {th }}$ century

2. Teaching and research. Research was incorporated as another mission of the university in the first academic revolution (from the late $19^{\text {th }}$ century)

3. Teaching, research and direct contribution to social and economic development, or the so-called Third Mission. Incorporating the Third Mission as another mission is known as the second academic revolution (from the end of the $20^{\text {th }}$ century).

The relation between the university and its socioeconomic environment can be defined as a set of processes and practices that go to make up technology transfer mechanisms, where the academic and administrative elements of the university establish relations with one another and with the outside in order to carry out actions and projects that yield benefits for everyone (Gould, 1997). 
Technology transfer mechanisms (TTMs henceforth) are the practical means by which interaction is established between the university and its socioeconomic environment. Several studies have focused on the interaction between the university and its socioeconomic environment through these mechanisms. Most of them concentrate on the relation between university and business, and develop econometric models based on information provided by different universities through surveys, semi-structured interviews and structured interviews. The aim of these studies is to analyse the attitudes of faculty members with regard to technology transfer (Lee, 1996; Etzkowitz, 1998), the characteristics of the interaction process (Meyer-Krahmer and Schmoch, 1998; Mead et al., 2004) and the organisational problems involved in the linking process (Sieguel et al., 2004).

Some of the more important TTMs that have recently appeared include research or technological spin-offs or joint ventures, business incubators and technology parks. These options complement and reinforce the traditional methods, such as human resources training schemes, industrial training units, academic consultancy, scientific and technological services, recruitment of future professionals, joint or specific contract research projects on technological innovation, the use of university facilities, use of licences to make use of inventions developed by others (Huanca, 2004; Lee et al., 2004; Sieguel et al., 2004; Stephan, 2001; Mead et al., 1999).

In some other studies, specifically related to the teaching-research nexus, researchers focus on surveys and to a lesser extent interviews to academics in order to measure to what extent research objectives fulfil teaching objectives according to their perception. . As we have seen in the Literature, there have been numerous quantitative attempts to account for the relationship between research and teaching by correlating teaching effectiveness measured through student evaluations of teaching, and research productivity measured through publication counts (Feldman 1987; Hattie and Marsh 1996). These studies suggest little or no relationship. In contrast, qualitative studies focusing on academics' perceptions and experiences have most often indicated a strong belief in the existence of, and need for, a symbiotic relationship in which involvement in research enhances teaching and, to a lesser extent, involvement in teaching stimulates research (Jensen 1988; Neumann 1992, 1993; Rowland 1996; Smeby 1998). 
Our proposal goes therefore a step further by introducing the use of MCDA in qualitative studies. From the different existing MCDA techniques, the use of ANP (Saaty, 1996) y AHP (Saaty, 1980) will provide a better approach for modelling the complex environment of the university because they allow the general study of both quantitative and qualitative variables and are particularly useful when working in contexts of scarce information.

The aim of this study is thus to propose a method for analysing the degree of alignment between the objectives stated by the University and the objectives achieved through the actions that are actually carried out by the University. This will enable the academic authorities to introduce corrective measures should any deviations be detected.

This model and the theoretical tools on which it is based are described below. To demonstrate its validity, the model was applied to the National University of Colombia - Bogotá Campus.

\section{Background of MCDM. The AHP and ANP techniques}

The Analytic Hierarchy Process and the Analytic Network Process are two methods proposed by Saaty $(1980,1996)$ that belong to the field of Multi-Criteria Decision Analysis (MCDA). MCDA "is a term that includes a set of concepts, methods and techniques that seek to help individuals or groups to make decisions, which involve several points of view in conflict and multiple stakeholders" (Belton and Stewart, 2002). All these MCDA concepts and methods have been widely studied in the Operational Research Literature (Pomerol and Barba-Romero, 2000; Belton and Stewart, 2002; Figueira et al., 2005). Selection of the proper MCDA technique is not easy. According to Bouyssou et al. (2000), there are several models that can be used in a decision-making process and there is no best model. In this paper, the use of two wellknown MCDA techniques is proposed, that is, Analytic Hierarchy Process and Analytic Network Process. Combining them allows us to use the one that offers most advantages in each step of the model. 
The AHP method has been proposed in the present work to directly assign priorisations to the university objectives. AHP is conceptually easy to use, however its strict hierarchical structure cannot handle the complexities of many real world problems. As a solution, Saaty proposed the ANP, the general form of the AHP. The ANP represents a decision making problem as a network of criteria and alternatives (all called elements), grouped into clusters. All the elements in the network can be related in any possible way, i.e. a network can incorporate feedback and interdependence relationships within and between clusters. This provides a more realistic modelling of complex settings. The influence of the elements in the network on other elements in that network can be represented in a supermatrix. This new concept consists of a two-dimensional elementby-element matrix which adjusts the relative importance weights in individual pairwise comparison matrices to build a new overall supermatrix with the eigenvectors of the adjusted relative importance weights.

The ANP-based approach has been proposed in this work to assign priorisations to the university objectives taken into account the actions implemented to establish the relationship with the socioeconomic environment.

This method is particularly suitable for problems with little and uncertain information, using qualitative criteria which are not independent of each other (Saaty, 1996), as is the case of socio-economic assessment environments.

Finally, these two priorisations will be compared.

The AHP technique has been being applied in many different cases in the last years (Vaidya and Kumar, 2006).

The ANP technique has already been used in different decision-making problems such as prioritising and designing rule changes for the game of soccer (Partovi and Corredoira, 2002), warehouse location for Digital Equipment Corporation (Sarkis and Sundarraj, 2002), contractor selection (Cheng and Li, 2004), acquisition of new machine tools in an enterprise (Yurdakul, 2004), financial crisis forecasting (Niemira and Saaty, 2004), choice of best management alternative for the supply chain in a company (Agarwal et al., 2006), determination of appropriate energy policies (Haktanırlar, 2005), selection of best actuation for end-of-life computers (Ravi et al., 
2005), product mix planning (Chung et al., 2005), evaluation of alternative fuels for residential heating (Erdoğmuş et al., 2006) and asset appraisal (Aragonés et al., 2008), ( García-Melón et al., 2007). However, no reports of applying ANP to analyse University STRATEGIC objectives have yet been published.

\section{The method of analysis and facilitating process}

The method of analysis proposed here takes into account the characteristics of the alignment problem (stated in point 1) that we intend to analyse, the general stages of the decision process (Aragonés, 1995) and those that are specific to the multi-criteria decision techniques that are applied, that is, AHP and ANP. Since this method is a novel application for the University in its problem structuring and MCDA techniques are unknown for the experts who collaborate in the study, it has been necessary to stress the role of the facilitator during the whole process.

The following figure shows the different steps in the methodology:

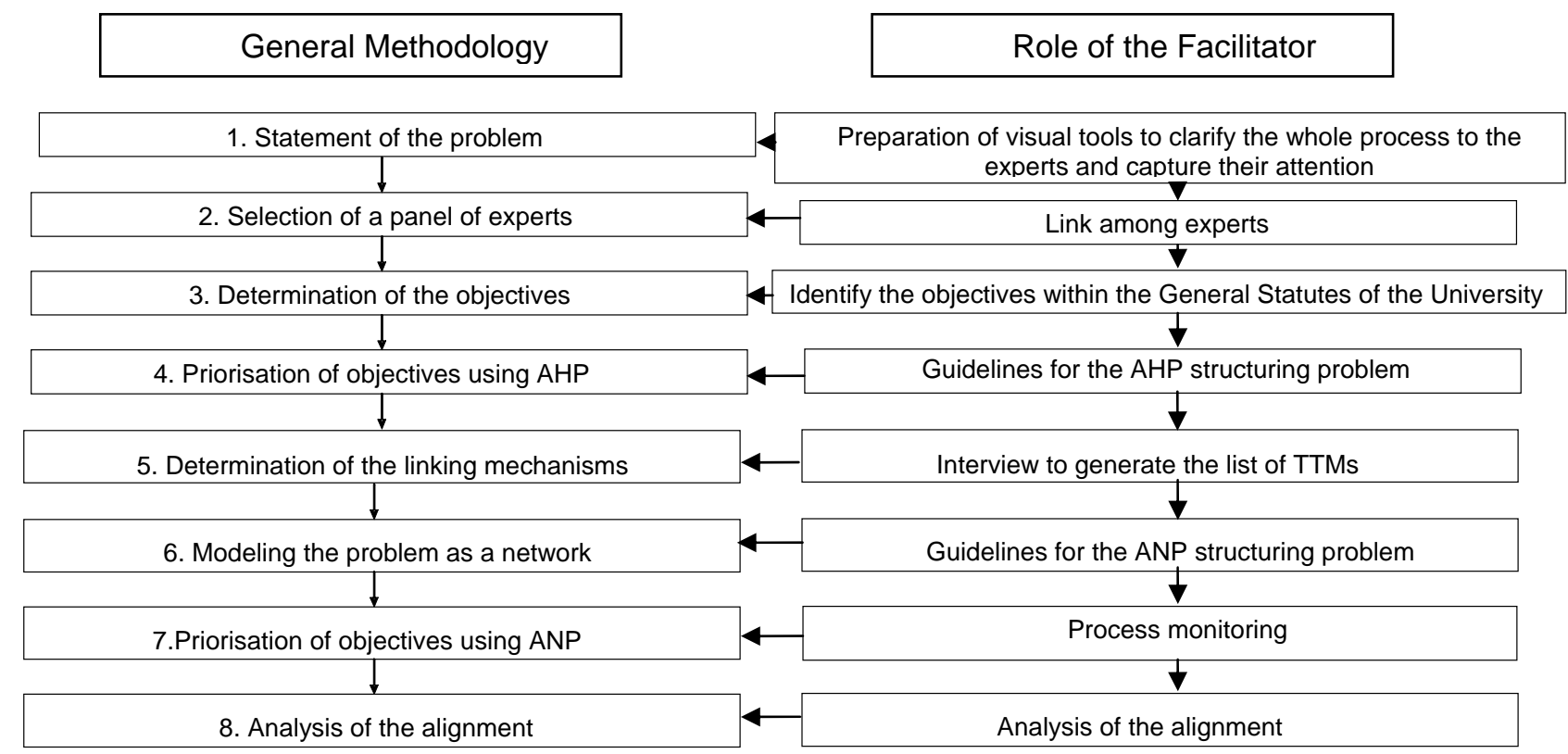

Figure 1. Stages of the proposed methodology for alignment with AHP and ANP

\subsection{Step 1: Statement of the problem}

The first step of the methodology consists in gathering information in order to build up a detailed knowledge of the links between the university and its socioeconomic environment. Such information is generally to be found in the Articles of Association or in the Strategic Plans of the University. 
In this phase, the Facilitator develops an understanding of the group and creates an expectation of their attitude towards the process designed and the outcomes intended.

\subsection{Step 2: Selection of a panel of experts}

In order to endow the results with a higher value, it is advisable to have several experts take part in solving the problem of prioritisation (Aragonés, 2001); these specialists are going to act as "decision-makers". For this study we recommend that at least one member from each of the functional areas of the university should be included in the panel of experts: Governing Body, Research Institutes and University Extension Divisions (Jharkharia et al., 2005). The experts must be selected bearing in mind their knowledge and experience in links between the university and its socioeconomic environment as well as the time they have available to participate in the study (Goodwin and Wright, 2004). Furthermore, the Facilitator must look for experts who ensure honest, fair answers to the questions asked in the research and act as their link (Saaty, 1996).

\subsection{Step 3: Determination of the objectives}

From the information collected in Step 1 about the objectives of the university and by interviewing the experts selected, the Facilitator goes on to identify and confirm the university's objectives regarding its socioeconomic environment. The experts should be interviewed as many times as necessary to reach an agreement on the list of objectives.

\subsection{Step 4: Prioritisation of the objectives}

Following the AHP approach, each expert must assign an importance to each objective stated. To do so, they must make a series of pairwise comparisons between the objectives defined in Step 3, issuing their judgements individually according to their knowledge and experience and on the basis of the Saaty scale.

The correct understanding of the method and its philosophy, as well as the questionnaire designed for this purpose (see Annex 1), are the main tasks of the Facilitator.

The individual judgements of all the experts will then be integrated to establish a single value for the priorities of the objectives; this is calculated by finding the geometric mean of those judgements (Saaty, 1980).

\subsection{Step 5: Determination of the technology transfer mechanisms}


From the information collected in Step 1 and by interviewing the experts who were selected, the Facilitator has to identify TTMs that are working, that are recognised by the university community and that have the greatest influence on the outcomes of the objectives regarding the socioeconomic environment. Interviews should be carried out until an agreement is reached on the list of TTMs.

\subsection{Step 6: Definition of the ANP model}

The information that was collected about the TTMs and the University's objectives regarding its socioeconomic environment is then taken as the basis on which to build an ANP model. TTMs were grouped in the network in accordance with the three missions of the University. Facilitator plays an essential role to build the ANP network, grouping the criteria and alternatives as Table 1.

\begin{tabular}{|l|l|}
\hline $\begin{array}{l}\text { Component of the ANP } \\
\text { network }\end{array}$ & $\begin{array}{l}\text { Equivalence in the model of the } \\
\text { University }\end{array}$ \\
\hline Clusters of criteria & $\begin{array}{l}\text { The three missions: teaching, } \\
\text { research and the third mission. }\end{array}$ \\
\hline $\begin{array}{l}\text { Elements of the clusters of } \\
\text { criteria }\end{array}$ & $\begin{array}{l}\text { TTMs used for each mission (step } \\
5)\end{array}$ \\
\hline Cluster of alternatives & $\begin{array}{l}\text { Objectives of the University (step } \\
3)\end{array}$ \\
\hline
\end{tabular}

Table 1. Equivalence between the components the ANP network and the model of the University

\subsection{Step 7: Prioritisation of objectives using ANP}

The application of ANP has been included as a single step in the methodology proposed here and its only objective is to obtain the total weights of the objectives of the university (alternatives according to the ANP model, taking into account all the influences of the network). Since the application of the method is complicated, a thorough monitoring of the whole process has to be carried out by the Facilitator.

\subsection{Step 8: Analysis of the alignment}

In the this step, the results of the theoretical prioritisation of the university's objectives obtained by the experts (based on AHP) are compared with the prioritisation of 
objectives achieved by considering the results accomplished in the TTMs obtained by the experts (based on ANP).

This last exercise will also enable to obtain an approximate measure of how much value or influence is contributed by TTM.

Taking these two prioritisations of the objectives into account, it becomes possible to answer the question: Are the university objectives (expected case) aligned with the outcomes achieved through the TTMs (actual case).

\section{Case study: National University of Colombia - Bogotá Campus (UNC-Bogotá)}

The methodology was applied to the National University of Colombia at its Bogotá campus (UNC-Bogotá - www.unal.edu.co), one of the most important institutions of higher education in Colombia.

\subsection{Step 1. Statement of the problem}

For this study two of the authors acted as facilitators of the process. One of them responsible of the face-to-face work with the group of experts in Bogotá (Colombia) and the other one located in Valencia (Spain) to help on the design of the whole monitoring process. The nature and objectives of the National University of Colombia are set out in its General Statutes, Agreement 11 of 2005. The TTMs were formalised by means of Agreement 004 of 2001.

\subsection{Step 2. Selection of the panel of experts}

Two groups of experts collaborated in this study. The first group, whose aim was to give their opinion in order to weight the objectives declared by the University, was made up of ten people: 3 experts from the Governing Body on a national level, 2 experts who were members of Research Institutes and 5 experts from the Faculty level who work in the Extension Divisions. After being informed about the study, they all collaborated by answering the questionnaires.

The second group, who were to determine the actual degree to which the objectives were being achieved through TTMs, was made up of members of staff from the Faculties with the highest levels of participation in university extension projects registered throughout the year 2006: 3 Experts of the Faculty of Arts, 4 Experts of the 
Faculty of Economics, 3 Experts of the faculty of Medicine, 4 experts of the Faculty of Engineering

The Facilitator was able to group all the first team of experts in a face-to-face meeting to solve the objectives priorisation problem by means of AHP.

However, they were not able to group all the second team of experts to solve the ANP priorisation problem and therefore the questionnaires were answered individually.

\subsection{Step 3. Determination of the objectives}

From the information obtained in the General Statutes of the National University of Colombia (Agreement 11 of 2005) and in collaboration with the experts, the Facilitator identified the objectives that are directly associated to the relation between the university and its socioeconomic environment, which were as follows:

1. To create and incorporate advanced knowledge at a national and international level

2. To train citizens, professionals and researchers

3. To study and analyse national problems and propose solutions

4. To benefit the local community with its academic activities

5. To participate in external organisations.

\subsection{Step 4. Prioritisation of the objectives using AHP}

The necessary guidelines to construct the AHP model were explained to the experts. A questionnaire was designed and also explained to the experts. Each questionnaire contained a total of 10 questions (see annex 1). Each expert used the questionnaire to establish his priorities of the objectives through pairwise comparisons. For surveys in which the inconsistency value was above $10 \%$, the Facilitator attempted to correct that value by asking the experts again, and they ratified them. In view of this situation and taking into account the results obtained by $\mathrm{Xu}$ (2000) and Escobar (2004), the Facilitator decided to continue with the process provided that the inconsistency achieved by combining the evaluations of the different experts was below $10 \%$.

The calculations for the AHP were performed by the facilitators with the help of the ExpertChoice $2000^{\odot}$ computer program.

Figure 2. Hierarchy of objectives using AHP 


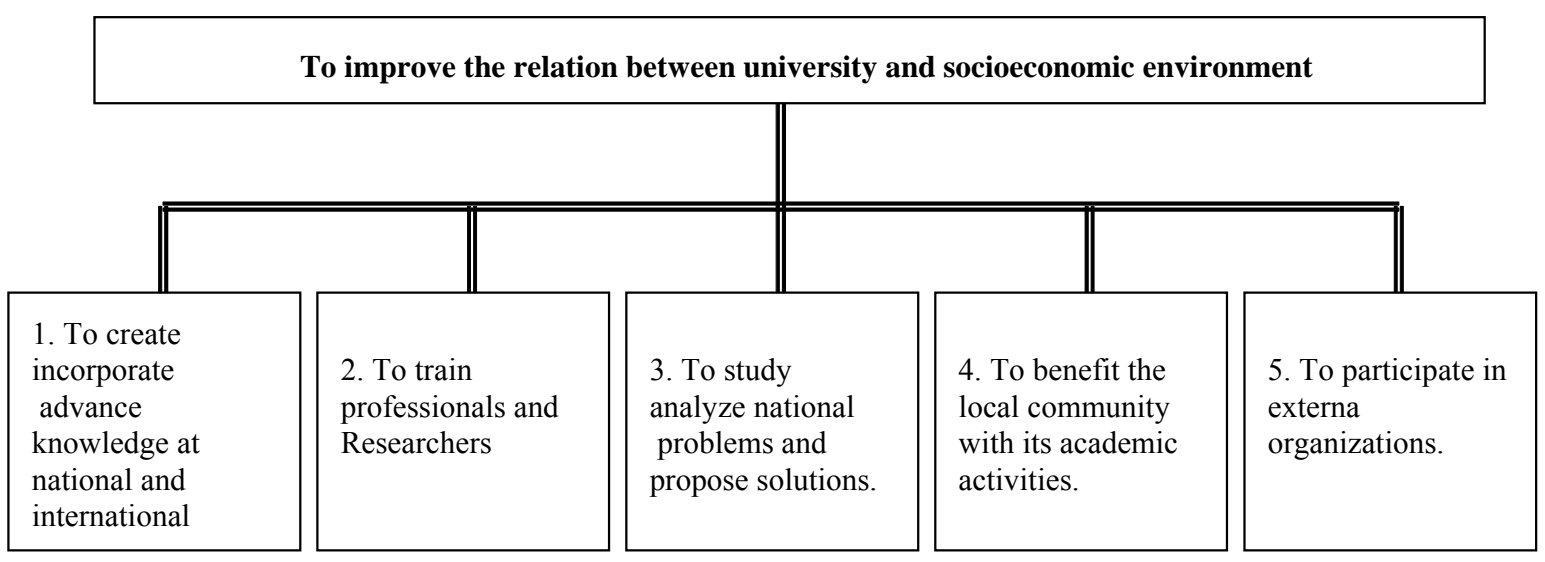

The results obtained in this prioritisation for the experts as a whole are represented as follows:

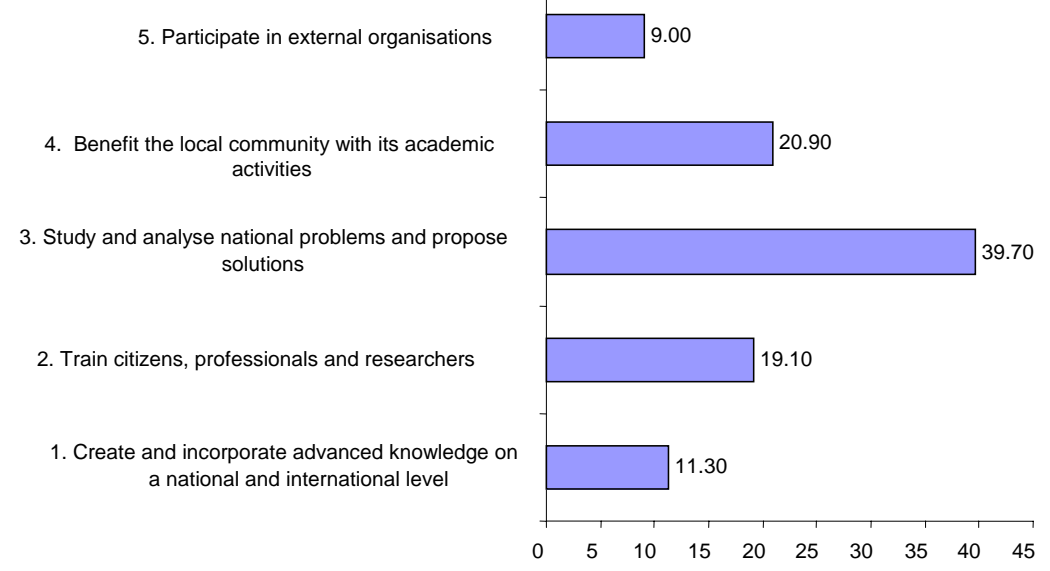

Figure 3. Prioritisation of the objectives regarding the relation between the university and its socioeconomic environment (AHP)

According to these results objective 3 and objective 4 account for over $50 \%$ of the undertakings: (i) To study and analyse national problems and propose solutions; and (ii) To benefit the local community with its academic activities. The UNC-Bogotá must therefore mainly focus on fulfilling these two objectives.

\subsection{Step 5. Determination of the technology transfer mechanisms}

Through several interviews held individually with the experts and bearing in mind the regulations governing university extension (Agreement 11 of 2005), ten fundamental TTMs were identified by the Facilitator for consideration within the relation between the university and its socioeconomic environment. These were: 
1. Continuing education.

2. Educational consultants and advisory services.

3. Work placements.

4. Human resources training programmes.

5. Contract research.

6. Internships in public (state-run) or private research centres (run by the industry or by enterprises).

7. Joint research projects.

8. Science and technology consultants and advisory services.

9. Internships in public (government-run) or private institutions (run by the industry or by enterprises).

10. Social or welfare programmes.

\subsection{Step 6. Modelling the problem as a network}

In this step, TTMs were classified into clusters within each of the missions of the UNCBOGOTA.

Figure 4 shows a representation of the problem using a network. 


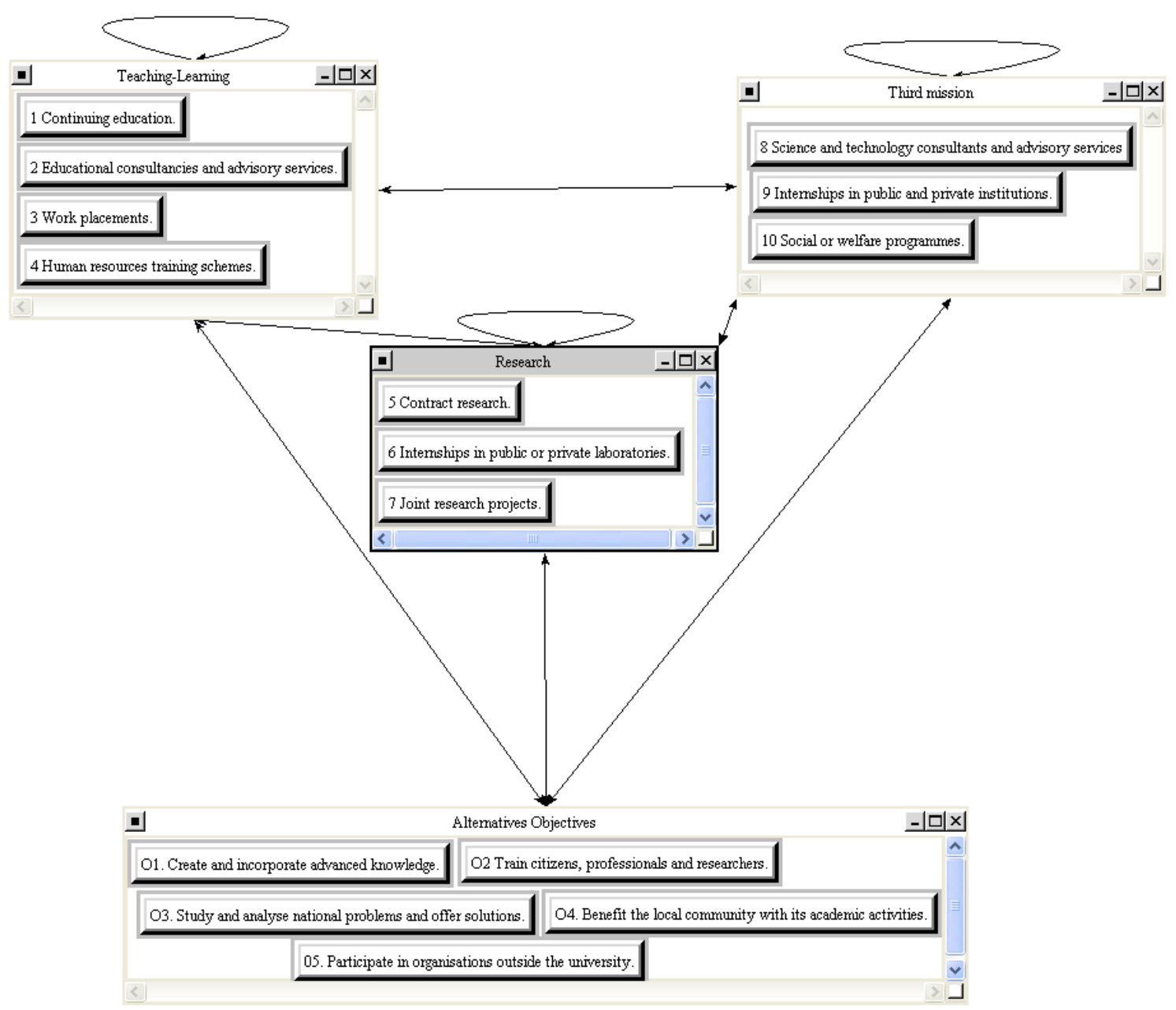

Figure 4. Technology transfer mechanisms linked to the different missions

The previous model consists of four clusters which correspond to the three missions of the University and their objectives. Furthermore, each mission contains certain TTMs that are related to one another. The network of influences among the elements in each cluster that was put forward by the experts can be seen in the following interfactorial domination matrix: 


\begin{tabular}{|c|c|c|c|c|c|c|c|c|c|c|c|c|c|c|c|c|}
\hline \multicolumn{2}{|l|}{$\begin{array}{l}\text { Interfactorial } \\
\text { domination matrix }\end{array}$} & \multicolumn{4}{|c|}{$\begin{array}{l}\text { Teaching- } \\
\text { Learning }\end{array}$} & \multicolumn{3}{|c|}{ Research } & \multicolumn{3}{|c|}{$\begin{array}{l}\text { Third } \\
\text { Mission }\end{array}$} & \multicolumn{5}{|c|}{ University's objectives } \\
\hline & & $\overline{1}$ & 2 & 3 & 4 & 5 & 6 & 7 & 8 & $\overline{9}$ & 10 & F1 & F2 & F3 & F4 & $\mathrm{F} 5$ \\
\hline \multirow{4}{*}{ Teaching-Learning } & 1 & 0 & 1 & 1 & 1 & 1 & 1 & 1 & 1 & 1 & 1 & 0 & 1 & 1 & 1 & 1 \\
\hline & 2 & 1 & 0 & 1 & 1 & 1 & 1 & 1 & 1 & 1 & 1 & 0 & 1 & 1 & 1 & 1 \\
\hline & 3 & 1 & 1 & 0 & 1 & 1 & 1 & 1 & 1 & 1 & 1 & 0 & 1 & 1 & 1 & 1 \\
\hline & 4 & 1 & 1 & 1 & 0 & 1 & 1 & 1 & 1 & 1 & 1 & 0 & 1 & 1 & 1 & 1 \\
\hline \multirow{3}{*}{ Research } & 5 & 1 & 1 & 1 & 1 & 0 & 1 & 1 & 1 & 1 & 1 & 1 & 1 & 1 & 1 & 1 \\
\hline & 6 & 1 & 1 & 1 & 1 & 1 & 0 & 1 & 1 & 1 & 1 & 1 & 1 & 1 & 1 & 1 \\
\hline & 7 & 1 & 1 & 1 & 1 & 1 & 1 & 0 & 1 & 1 & 1 & 1 & 1 & 1 & 1 & 1 \\
\hline \multirow{3}{*}{ Third Mission } & 8 & 1 & 1 & 1 & 1 & 1 & 1 & 1 & 0 & 1 & 1 & 1 & 1 & 1 & 1 & 1 \\
\hline & 9 & 1 & 1 & 1 & 1 & 1 & 1 & 1 & 1 & 0 & 1 & 1 & 1 & 1 & 1 & 1 \\
\hline & 10 & 1 & 1 & 1 & 1 & 1 & 1 & 1 & 1 & 1 & 0 & 1 & 1 & 1 & 1 & 1 \\
\hline \multirow{5}{*}{ University's objectives } & $\overline{F 1}$ & 0 & 0 & 0 & 0 & 1 & 1 & 1 & 1 & 1 & 1 & 0 & 0 & 0 & 0 & 0 \\
\hline & $\mathrm{F} 2$ & 1 & 1 & 1 & 1 & $\frac{\Delta}{1}$ & 1 & 1 & 1 & 1 & 1 & 0 & 0 & 0 & 0 & 0 \\
\hline & F3 & 1 & 1 & 1 & 1 & 1 & 1 & 1 & 1 & 1 & 1 & 0 & 0 & 0 & 0 & 0 \\
\hline & F4 & 1 & 1 & 1 & 1 & 1 & 1 & 1 & 1 & 1 & 1 & 0 & 0 & 0 & 0 & 0 \\
\hline & F5 & 1 & 1 & 1 & 1 & 1 & 1 & 1 & 1 & 1 & 1 & 0 & 0 & 0 & 0 & 0 \\
\hline
\end{tabular}

Table 2. Interfactorial domination matrix.

From this matrix it can be concluded that most of the TTM are related to each other.

\subsection{Step 7. Prioritisation of objectives using ANP}

The ANP model was evaluated by the second group of experts selected in Step 2. For the case study, four questionnaires were designed and then given out in each of the Extension Centres in the Faculties of Art, Medicine, Engineering and Economics (see Annex 2). Each questionnaire contained a total of 234 questions (see Annex 3).

Each expert drew on his individual experience and knowledge to answer the questionnaires in order to assess the relationships according to the model shown in Figure 4. After a reflection on the clusters conducted by the Facilitator, the experts agreed that the weights of the four different clusters had to be the same.

For the surveys that had an inconsistency value above $10 \%$, the Facilitator attempted to reduce the value by asking the experts again, and they ratified them. In view of this situation and in the same way as in the AHP stage, it was decided to continue with the process provided that the inconsistency achieved by combining the evaluations of the different experts was below 10\% (Xu, 2000; Escobar, 2004).

The agreed values were entered in the Superdecisions ${ }^{\complement}$ software by the Facilitator. The following matrices were 
obtained:

\begin{tabular}{|c|c|c|c|c|c|c|c|c|c|c|c|c|c|c|c|c|}
\hline & \multicolumn{4}{|c|}{ Teaching-Learning } & \multicolumn{3}{|c|}{ Research } & \multicolumn{3}{|c|}{ Third Mission } & \multicolumn{5}{|c|}{ University's Objectives } \\
\hline & & 1 & 2 & 3 & 4 & 5 & 6 & 7 & 8 & 9 & 10 & F1 & $\mathrm{F} 2$ & F3 & $\mathrm{F} 4$ & F5 \\
\hline \multirow{4}{*}{ 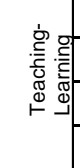 } & 1 & 0.00000 & 0.13501 & 0.58415 & 0.13500 & 0.27451 & 0.15849 & 0.15849 & 0.21726 & 0.14062 & 0.21725 & 0.00000 & 0.18084 & 0.12155 & 0.17371 & 0.14031 \\
\hline & 2 & 0.10473 & 0.00000 & 0.13501 & 0.28083 & 0.47549 & 0.27452 & 0.47549 & 0.39555 & 0.30561 & 0.39554 & 0.00000 & 0.31481 & 0.24865 & 0.28073 & 0.25451 \\
\hline & 3 & 0.25828 & 0.28082 & 0.00000 & 0.58417 & 0.15849 & 0.47548 & 0.09150 & 0.08727 & 0.36830 & 0.08728 & 0.00000 & 0.24304 & 0.20093 & 0.29933 & 0.25390 \\
\hline & 4 & 0.63699 & $\mid 0.58417$ & 0.28084 & 0.00000 & 0.09151 & 0.09151 & 0.27452 & 0.29992 & 0.18546 & 0.29993 & 0.00000 & 0.26130 & 0.42887 & 0.24622 & 0.35127 \\
\hline \multirow{3}{*}{ 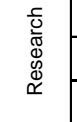 } & 5 & 0.58415 & 0.63698 & 0.28083 & 0.68542 & 0.00000 & 0.50000 & 0.83333 & 0.63698 & 0.31892 & 0.20000 & 0.21477 & 0.14471 & 0.24401 & 0.17407 & 0.11944 \\
\hline & 6 & 0.28083 & 0.10473 & 0.58416 & 0.08017 & 0.16667 & 0.00000 & 0.16667 & 0.10473 & 0.22112 & 0.19999 & 0.23701 & 0.38860 & 0.12399 & 0.17633 & 0.14446 \\
\hline & 7 & 13501 & 0.25829 & 0.13501 & 3441 & 0.83333 & 0.50000 & 0000 & 0.25829 & 0.45997 & 0.60001 & 0.54822 & 0.46669 & 200 & 54960 & 0.73611 \\
\hline \multirow{3}{*}{ 总 } & 8 & 0.33333 & 0.58415 & 0.28083 & 0.58415 & 0.63698 & 0.42857 & 0.48064 & 0.00000 & 0.50000 & 0.83333 & 0.26834 & 0.21012 & 0.34660 & 0.32189 & 0.31506 \\
\hline & 9 & 33333 & 0.28083 & 0.58416 & 0.13501 & 0.10473 & 0.42857 & 0.11397 & 0.24998 & 0.00000 & 0.16667 & 0.09789 & 0.20998 & 0.09402 & 0.09637 & 0.13143 \\
\hline & 10 & 333 & 3501 & 01 & 34 & 29 & 36 & 39 & 02 & 00 & 00 & 3377 & 90 & 38 & 58174 & 0.55351 \\
\hline \multirow{5}{*}{ 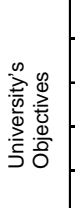 } & $\mathrm{F} 1$ & 0.00000 & 0.00000 & 0.00000 & 0.00000 & 0.24741 & 0.06814 & 0.27416 & 0.12752 & 0.12588 & 0.08769 & 0.00000 & 0.00000 & 0.00000 & 0.00000 & 0.00000 \\
\hline & $\mathrm{F} 2$ & 0.25908 & 0.26788 & 0.38369 & 0.23958 & 0.18230 & 0.17652 & 0.12712 & 0.11573 & 0.28525 & 0.10053 & 0.00000 & 0.00000 & 0.00000 & 0.00000 & 0.00000 \\
\hline & F3 & 0.15819 & 0.32717 & 0.12401 & 0.37383 & 0.20672 & 0.31784 & 0.31920 & 0.37244 & 0.28607 & 0.28713 & 0.00000 & 0.00000 & 0.00000 & 0.00000 & 0.00000 \\
\hline & F4 & 0.41199 & 0.29676 & 0.24236 & 0.21313 & 0.23619 & 0.32937 & 0.14990 & 0.23798 & 0.07898 & 0.25816 & 0.00000 & 0.00000 & 0.00000 & 0.00000 & 0.00000 \\
\hline & F5 & 0.17074 & 0.10818 & 0.24994 & 0.17345 & 0.12739 & 0.10813 & 0.12961 & 0.14633 & 0.22381 & 0.26648 & 0.00000 & 0.00000 & 0.00000 & 0.00000 & 0.00000 \\
\hline
\end{tabular}

Table 3. Unweighted supermatrix

\begin{tabular}{|c|c|c|c|c|c|c|c|c|c|c|c|c|c|c|c|c|}
\hline & \multicolumn{4}{|c|}{ aching-Learning } & \multicolumn{3}{|c|}{ ch } & \multicolumn{3}{|c|}{ ird Mission } & \multicolumn{5}{|c|}{ University's Objectives } \\
\hline & & 1 & & 3 & 4 & 5 & & 7 & 8 & 9 & 10 & F1 & $\mathrm{F} 2$ & $\mathrm{F3}$ & $\mathrm{F} 4$ & F5 \\
\hline \multirow{4}{*}{ 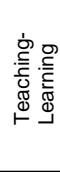 } & 1 & 00000 & 0.03375 & 4604 & 3375 & 06863 & 03962 & 03962 & 05431 & 0.03516 & 31 & 0000 & 0.06028 & 0.04052 & .05790 & 046 \\
\hline & 2 & 02618 & 00000 & 3375 & 57021 & 1887 & 06863 & 1887 & 9889 & 07640 & 09889 & 0000 & 0494 & 08288 & 09358 & 84 \\
\hline & 3 & 06457 & D7021 & 00000 & 14604 & 03962 & 11887 & 2288 & 2182 & 09208 & 0218 & 00000 & 0810 & 06698 & 0997 & 88464 \\
\hline & 4 & 15925 & 14604 & 7021 & 0.00000 & 02288 & 02288 & 06863 & 07498 & 0.04637 & 07498 & 00000 & 087 & 14296 & $082 C$ & 11709 \\
\hline \multirow{3}{*}{ 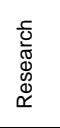 } & 5 & 4604 & 5925 & 7021 & 17136 & 0000 & 2500 & 083 & 15925 & 07973 & 05000 & 739 & & 0813 & & 03 \\
\hline & 6 & 07021 & 2618 & 4604 & 2004 & 4167 & 00000 & 4167 & 2618 & 05528 & 05000 & 851 & & 梦 & $05 \varepsilon$ & 048 \\
\hline & 7 & 03375 & 6457 & 3375 & 05860 & 20833 & 12500 & 0000 & 6457 & 11499 & 1500 & . & 155 & 2106 & 216 & 245 \\
\hline \multirow{3}{*}{ 菅高帝 } & 8 & 08333 & 4604 & 7021 & 0.14604 & 15925 & 10714 & 2016 & 00000 & 0.12500 & 20833 & 13417 & 07 & 1155 & 10730 & 105 \\
\hline & 9 & 88333 & 7021 & 4604 & 0.03375 & 02618 & 10714 & 02849 & 06250 & 0.00000 & 04167 & 04895 & 0.06 & 03134 & .03212 & 04 \\
\hline & 10 & 08333 & 3375 & 3375 & 0.07021 & 06457 & 03571 & 0135 & 18751 & 0.12500 & .00000 & 31689 & 0.19 & .1864 & 0.19391 & 0.18450 \\
\hline \multirow{5}{*}{ 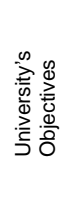 } & F1 & 00000 & 00000 & 00000 & 00000 & 06185 & 01704 & 6854 & 03188 & 0.03147 & 0219 & 0000 & 0.000 & 000 & .000 & 0.0000 \\
\hline & F2 & 0.06477 & 66697 & 9592 & 0.05990 & 04557 & 04413 & 3178 & 02893 & 0.07131 & 02513 & 00000 & 0.000 & 更 & ser & 年 \\
\hline & F3 & 555 & 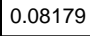 & 100 & 0.09346 & 5168 & 946 & & & 7152 & & & & & $x_{2}$ & \\
\hline & F4 & 300 & 19 & 06059 & 0.05328 & 05905 & 34 & 03748 & 50 & 75 & 0.064 & م & 10000 & 00000 & 0000 & م00000 \\
\hline & F5 & 04268 & 02705 & 19 & 0.04336 & 0.03185 & 03 & 03240 & 03658 & 0.05595 & 0.06662 & & 0 & 000000 & 0.000 & (20000 \\
\hline
\end{tabular}

Table 4. Weighted supermatrix 


\begin{tabular}{|c|c|c|c|c|c|c|c|c|c|c|c|c|c|c|c|c|}
\hline & \multicolumn{4}{|c|}{ Teaching-Learning } & \multicolumn{3}{|c|}{ Research } & \multicolumn{3}{|c|}{ Third Mission } & \multicolumn{5}{|c|}{ University's Objectives } \\
\hline & & 1 & 2 & 3 & 4 & 5 & 6 & 7 & 8 & 9 & 10 & F1 & $\mathrm{F} 2$ & $\mathrm{~F} 3$ & $\mathrm{~F} 4$ & F5 \\
\hline \multirow{4}{*}{ 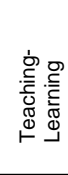 } & 1 & 0.04989 & 0.04989 & 0.04989 & 0.04989 & 0.04989 & 0.04989 & 0.04989 & 0.04989 & 0.04989 & 0.04989 & 0.04989 & 0.04989 & 0.04989 & 0.04989 & 0.04989 \\
\hline & 2 & 07967 & 0.07967 & 0.07967 & 0.07967 & 0.07967 & 0.07967 & 0.07967 & 0.07967 & 0.07967 & .07967 & 0.07967 & 0.07967 & 0.07967 & .07967 & 0.07967 \\
\hline & 3 & 0.05639 & 0.05639 & 0.05639 & 0.05639 & 0.05639 & 0.05639 & 0.05639 & 0.05639 & 0.05639 & 0.05639 & 0.05639 & 0.05639 & 0.05639 & 0.05639 & 0.05639 \\
\hline & 4 & 07311 & 0.07311 & 0.07311 & 0.07311 & 0.07311 & 0.07311 & 0.07311 & 0.07311 & 0.07311 & 0.07311 & 0.07311 & 0.07311 & 0.07311 & 0.07311 & 0.07311 \\
\hline \multirow{3}{*}{ 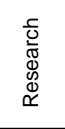 } & 5 & 0.10709 & 0.10709 & 0.10709 & 0.10709 & 0.10709 & 0.10709 & 0.10709 & 0.10709 & 0.10709 & 0.10709 & 0.10709 & 0.10709 & 0.10709 & 0.10709 & 0.10709 \\
\hline & 6 & 0.05002 & 0.05002 & 0.05002 & 0.05002 & 0.05002 & 0.05002 & 0.05002 & 0.05002 & 0.05002 & 0.05002 & 0.05002 & 0.05002 & 0.05002 & 0.05002 & 0.05002 \\
\hline & 7 & .11336 & 0.11336 & 0.11336 & 0.11336 & 0.11336 & 0.11336 & 0.11336 & 0.11336 & 0.11336 & 0.11336 & 0.11336 & 0.11336 & 0.11336 & 0.11336 & 0.11336 \\
\hline \multirow{3}{*}{ 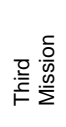 } & 8 & 11546 & 0.11546 & 0.11546 & 0.11546 & 11546 & 0.11546 & 0.11546 & 0.11546 & 0.11546 & 0.11546 & 0.11546 & 0.11546 & 0.11546 & 0.11546 & 0.11546 \\
\hline & 9 & 0.05197 & 0.05197 & 0.05197 & 0.05197 & 0.05197 & 0.05197 & 0.05197 & 0.05197 & 0.05197 & 0.05197 & 0.05197 & 0.05197 & 0.05197 & 0.05197 & 0.05197 \\
\hline & 10 & 0.10304 & 0.10304 & 0.10304 & 0.10304 & 0.10304 & 0.10304 & 0.10304 & 0.10304 & 0.10304 & 0.10304 & 0.10304 & 0.10304 & 0.10304 & 0.10304 & 0.10304 \\
\hline \multirow{5}{*}{ 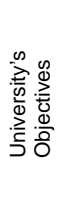 } & F1 & 0.02282 & 0.02282 & 0.02282 & 0.02282 & 0.02282 & 0.02282 & 0.02282 & 0.02282 & 0.02282 & 0.02282 & 0.02282 & 0.02282 & 0.02282 & 0.02282 & 0.02282 \\
\hline & $\mathrm{F} 2$ & 0.03868 & 0.03868 & 0.03868 & 0.03868 & 0.03868 & 0.03868 & 0.03868 & 0.03868 & 0.03868 & 0.03868 & 0.03868 & 0.03868 & 0.03868 & 0.03868 & 0.03868 \\
\hline & F3 & 0.05749 & 0.05749 & 0.05749 & 5749 & 5749 & 0.05749 & 5749 & 05749 & 0.05749 & 0.05749 & 0.05749 & 0.05749 & 5749 & 0.05749 & 0.05749 \\
\hline & F4 & 0.04760 & 0.04760 & 0.04760 & 0.04760 & 0.04760 & 0.04760 & 0.04760 & 0.04760 & 0.04760 & 0.04760 & 0.04760 & 0.04760 & 0.04760 & 0.04760 & 0.04760 \\
\hline & F5 & 0.03341 & 0.03341 & 0.03341 & 0.03341 & 0.03341 & 0.03341 & 0.03341 & 0.03341 & 0.03341 & 0.03341 & 0.03341 & 0.03341 & 0.03341 & 0.03341 & 0.03341 \\
\hline
\end{tabular}

Table 5. Limit supermatrix

The prioritisations obtained from the limit supermatrix:

5. To participate in external organisations

4. To benefit the local community with its academic activities

3. To study and analyse national problems and propose solutions

2. To train citizens, professionals and researchers

1. To creating and incorporate advanced know ledge at a national and international level

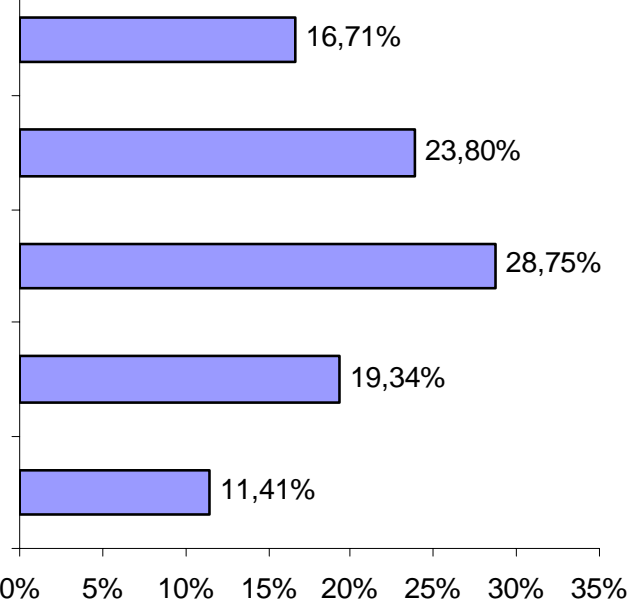

Figure 5. Prioritisation of the objectives regarding the relation between the university and its socioeconomic environment (ANP)

\subsection{Step 8. Analysis of the alignment}

In this last step, the results of the theoretical prioritisation of the university's objectives obtained by the experts (step 4) have to be compared with the prioritisation of objectives achieved by considering the results accomplished through the TTMs (step 7). The results obtained were the following: 


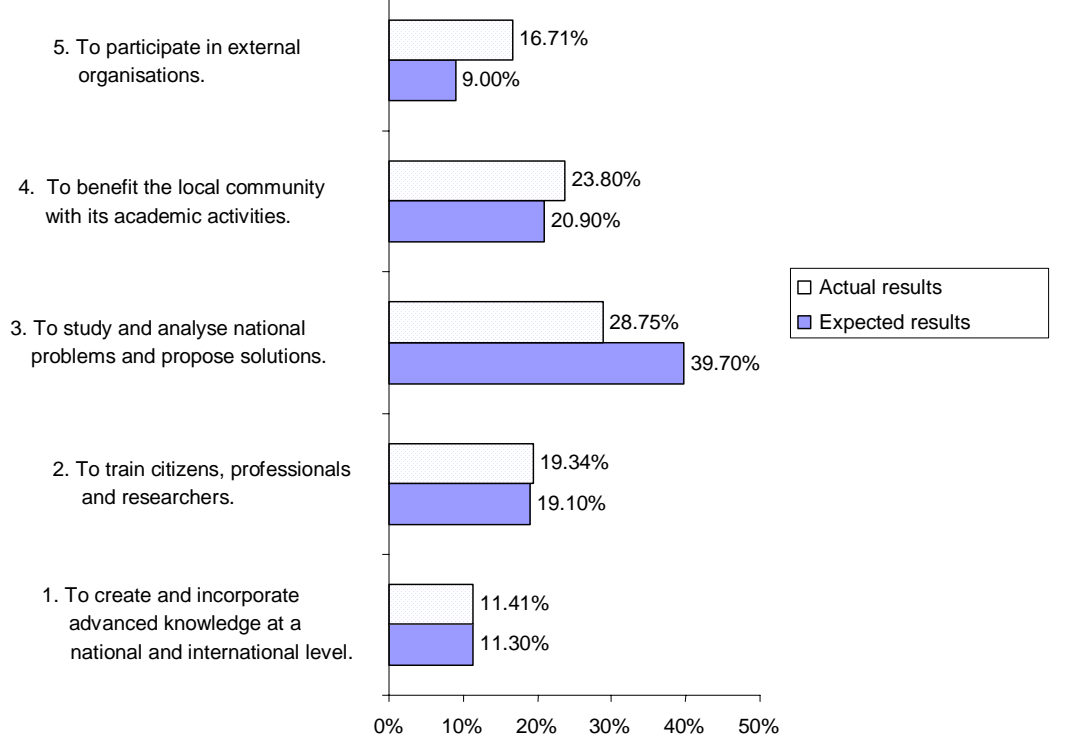

Figure 6. Objectives. Comparison of the results of priorisation.

Results show that in both cases the rank order of the first three most important objectives is maintained (obj.3, obj. 4, obj.2). There is an exchange in position only in the two less important objectives (obj 5 and obj.1). That means that there is only a small misalignment between the expected and the actual objectives.

Therefore, we can conclude that according to the experts the UNC-BOGOTA should commit itself mainly "To study and analyze national problems and propose solutions" and "To benefit the local community with its academic activities". Although these objectives accounted for more than $60 \%$ of the total in the evaluation, the objective "To study and analyze national problems and propose solutions" is below the experts' expectations, (with a value of $28,7 \%$ vs. $39.7 \%$ ) and the objective "To benefit the local community with its academic activities" exerts a greater influence than that given by the experts $(23,8 \%$ vs. 20,9\%). The objective "To train citizens, professionals and researchers" remains the third most important and influential in both cases with almost the same value $(19,3$ vs. 19,1$)$

Moreover, the objective "To participate in external organizations" has a level that is much higher than the experts' expectations, and is the situation that displays the biggest difference from what was suggested by the experts (16,71\% vs. 9,0\%). 
No greater differences were found between what the experts expected and what was achieved by TTMs.

The results are also presented from another point of view that allows a better understanding of the degree of alignment.

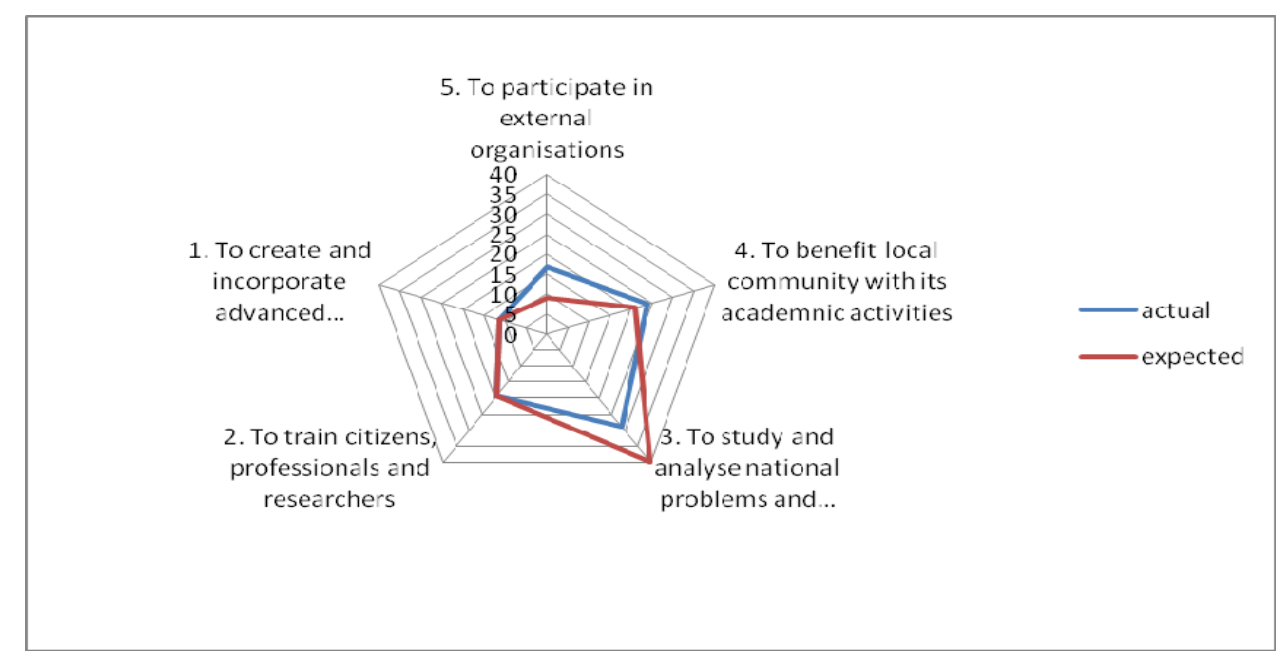

Figure 7. Comparison of the results of priorisation

This small misalignment is mainly due to the period of transition the University is currently undergoing. In this new stage, the new initiatives of the Governing Body are aimed at enhancing and complementing the Social Mission of the University or "University Extension" by encouraging a greater direct contribution to economic development through TTMs.

The influences of TTMs associated to each mission have also been obtained and are presented in the following table:

\begin{tabular}{|l|l|c|}
\hline \multicolumn{1}{|c|}{ Mission } & \multicolumn{1}{c|}{ Technology Transfer Mechanism } & $\%$ \\
\hline Third Mission & 8. Science and technology consultants and advisory services. & 14.40 \\
\hline Research & 7. Joint research & 14.20 \\
\hline Research & 5. Contract & 13.40 \\
\hline Third Mission & 10. Social or welfare programmes. & 12.90 \\
\hline Teaching-Learning & 2. Educational consultants and advisory services. & 10.00 \\
\hline Teaching-Learning & 4. Human resources training schemes. & 9.10 \\
\hline Teaching-Learning & 3. Work placements. & 7.00 \\
\hline Third Mission & 9. Internships in public and private institutions. & 6.50 \\
\hline Research & 6. Internships in public and private laboratories. & 6.30 \\
\hline Teaching-Learning & 1. Continuing education. & 6.20 \\
\hline
\end{tabular}

Table 7. Technology transfer mechanisms in descending order of influence. 
From the previous table it can be seen that the greatest influences are exerted by the TTMs associated with Research, with $27.6 \%$ (7 and 5), the Third Mission, with 27.3\% (8 and 10), and with Teaching-Learning, with 19.1\% (2 and 4). Practical work training (3, 9 and 6) in each of the areas shows the lowest levels of influence. Continuing Education (1) maintains its low level of influence in the field of Teaching-Learning.

The Facilitator submitted these results to the Governing Body, who considered them to be appropriate, relevant and close to the real situation, and will therefore be taken into account in defining future policies and strategies for enhancing the TTMs.

\section{Validation of the methodology}

It is difficult to test the validity of the model since it has not been analyzed using past data, due to the unavailability of past data for the particular case under study. This problem, however, should not be viewed as a significant shortcoming when evaluating the validity of the model. The comparison matrices that are the inputs to the suggested model are defined under known conditions. Thus it is possible to achieve different results since different pairwise comparison matrices may be obtained at different points in time.

However, throughout the process of applying the methodology, and more especially in the stage in which information was being collected by means of the questionnaires, the experts expressed their satisfaction not only in the results of the evaluation of the alignment but also in the tools used to carry out the analysis. The experts liked the methodology and the model. Since the Governing Body considered the results to be appropriate, relevant and close to the real situation, and wanted to take them into account in defining future policies and strategies for enhancing the TTMs, the Facilitator considered the methodology proposed useful.

\section{Final conclusions}

In this paper it is shown how it is possible to address such complex problems as measuring the alignment of strategic objectives of a university regarding its socioeconomic environment with the results achieved using its TTMs, by means of AHP and ANP techniques. During the work with the experts it became obvious that designing the hierarchy and the network requires experience in and knowledge of the 
problem being dealt with, and it is therefore essential to have a proper facilitating support all along the process.

By using the Analytic Hierarchy Process we have succeeded in prioritising the objectives of the university and proved that not all the objectives are equally important. In contrast, the Analytic Network Process allowed us to prioritise them according to the actual results that were obtained by the TTMs as regards the objectives of the university.

A comparison of the first prioritisation with the second one makes it possible to establish the degree of alignment of the university's objectives regarding its socioeconomic environment. Detecting a misalignment enables the university to apply corrective policies in order to accomplish the theoretical objectives.

The results obtained are of great value for decision-making in university policies concerning the strategies of technology transfer between the university and its local community. These results were submitted to the Governing Body of the National University of Colombia, Bogotá Campus, who saw it as being useful and very close to the situation the university is actually undergoing at the present time.

The authors of this work also want to highlight the deep thought triggered by the method. It forces us to analyse the objectives and their degree of importance according to different experts. It obliges us to identify and analyse TTMs and their influence. It produces an analysis for comparing what is desired with what we believe is being obtained.

Finally, it must be pointed out that in the Colombian university the AHP and the ANP can be used for a number of applications. These techniques can be used to support complex prioritisation and decision-making processes that are typically found in the university community. The following cases could be cited as examples: evaluating the merits of faculty members, university strategy planning; evaluation of research papers, assignation of the university budget, redesigning the curricula of Master's degrees, selection of members of teaching staff, evaluation of the effectiveness of the different teaching techniques for meeting training goals, assignation of university resources and 
planning the information infrastructure, and planning the university infrastructure, among other applications.

\section{References}

1. Agarwal, A., Shankar, R., Tiwari, M. K. Modeling the metrics of lean, agile and leagile supply chain: An ANP-based approach. European Journal of Operational Research 2006; 173 (1); 211-225.

2. Aragonés, P. Aproximación a la Toma de Decisiones Multicriterio en Proyectos. Implementación de una Metodología Multicriterio y Multiexperto: Pres II. Universidad Politécnica de Valencia; Valencia; 1995.

3. Aragonés, P., Gómez-Senent, E., Pastor, J., Ordering the Alternatives of a Strategic Plan of Valencia (Spain). Journal of Multicriteria Decision Analysis $2001 ; 10(3) ; 153-171$

4. Aragonés, P.; Aznar, J.; Ferrís-Oñate, J., García-Melón, M. Valuation of Urban Industrial Land: an Analytic Network Process Approach. European Journal of Operational Research 2008; 185 (1); 322-339

5. Belton V., Stewart T.J. Multi Criteria Decision Analysis: an integrated approach. Kluwer Academic Publishers, Boston; 2002.

6. Bouyssou, D., Marchant, T., Pirlot, M., Perny, P., Tsoukias, A, and Vincke, P. Evaluation and Decision Models: A Critical Perspective. Kluwer Academic Publishers; Boston; 2000.

7. Cheng, E.W.L., Li, H. Contractor selection using the analytic network process, Construction Management and Economics 2004; 22; 1021-1032.

8. Chung, S., Lee, A.H.I., Pearn, W.L. Analytic network process (ANP) approach for product mix planning in semiconductor Fabricator International. Journal of Production Economics 2005; 96; 15-36.

9. Erdogmus, Ş.L., Aras, H., Koç E. Evaluation of alternative fuels for residential heating in Turkey using analytic network process (ANP) with group decisionmaking. Renewable and Sustainable Energy Reviews 2004; 10 (3); 269-279. 
10. Escobar, M.T., Aguarón, J., Moreno-Jiménez J.M. A note on AHP group consistency for the row geometric mean priorisation procedure. European Journal of Operational Research 2004; 153; 318-322

11. Etzkowitz H., Leydesdorff L. The dynamics of innovation: from National Systems and "Mode 2" to a Triple Helix of university-industry-government relations. Research Policy 2000; 29; 109-123.

12. Etzkowitz, H. The norms of entrepreneurial science: cognitive effects of the new university industry linkages. Research Policy 1998; 27; 823-833.

13. Etzkowitz, H. Research groups as 'quasi-firms': the invention of the entrepreneurial university. Research Policy 2003; 32; 109-121.

14. Feldman, K. (1987). 'Research productivity and scholarly accomplishment of college teachers as related to their instructional effectiveness', Research in Higher Education 26(3), 227-291.

15. Figueira J., Greco S., Ehrgott M. Multiple criteria decision analysis: state of the art surveys, Springer, New York; 2005.

16. García-Melón, M.; Ferrís, J.; Aznar, J.; Aragonés, P.; Poveda-Bautista, R. Farmland appraisal: An Analytic Network Process approach. Journal of Global Optimization 2007, DOI 10.1007/s10898-007-9235-0.

17. Geuna, A. The internationalization of European universities: a return to medieval roots. Minerva XXXVI 1998; 3; 253-270.

18. Goodwin, P., Wright, G. Decision Analysis for Management Judgment. John Wiley and Sons. New York; 2004.

19. Gould, G.B. Vinculación universidad - sector productivo: una reflexión sobre la planeación y operación de programas de vinculación, ANUIES, Universidad Autónoma de Baja California; México; 1997.

20. Haktanırlar, B. Determination of the appropriate energy policy for Turkey. Energy 2005; 30; 1146-1161.

21. Hattie, J. and Marsh, H. (1996). 'The relationship between research and teaching: A meta-analysis', Review of Educational Research 66(4), 507-542. 
22. Huanca, R. La investigación universitaria de países en desarrollo y la visión de los académicos sobre la relación universidad empresa: Universidades públicas de la región occidental de Bolivia, Doctoral Thesis, Universidad Politécnica de Valencia: Valencia; 2004.

23. Jensen, J. (1988). 'Research and teaching in the universities of Denmark: Does such an interplay really exist?' Higher Education 17, 1-26.

24. Jharkharia, S., Shankar, R. Selection of logistics service provider: An analytic network process (ANP) approach. Omega, The International Journal of Management Science 2007; 35(3); 274-289.

25. Lee, Y. S. Technology transfer and the research university: a search for the boundaries of university collaboration. Research Policy 1996; 25; 843-863.

26. Mead N., Beckman K., Lawrence J., O’Mary G., Parish C. Industry/university collaborations: different perspectives heighten mutual opportunities. The Journal of Systems and Software 1999; 49; 155-162.

27. Meade, L.M., Sarkis, J. Analyzing organizational project alternatives for agile manufacturing processes: an analytical network approach. International Journal of Production Research 1999; 37 (2); 241-261.

28. Meyer-Krahmer, F., Schmoch, U. Science-based Technologies: universityindustry interactions in four fields. Research Policy 1998; 27; 835-851.

29. Neumann, R., Research and scholarship: perceptions of senior academic administrators, Higher Education 1993, 25, 97 - 110.

30. Neumann, R., Perceptions of the teaching-research nexus: a framework for analysis, Higher Education 1992, 23, 159-171.

31. Niemira, M. P., Saaty, T. L. An Analytic Network Process model for financialcrisis forecasting. International Journal of Forecasting 2004; 20; 573-587.

32. Partovi, F.Y., Corredoira, R. A. Quality function deployment for the good of soccer; European Journal of Operational Research 2002; 137; 642-656.

33. Pomerol and Barba-Romero (2000); Multicriterion decision in Management: Principles and Practice, Kluwer Academia, Boston, 2000 
34. Ravi, V., Shankar, R., Tiwari, M. K. Analyzing alternatives in reverse logistics for end-of-life computers: ANP and balanced scorecard approach, Computers \& Industrial Engineering 2005; 48; 327-356.

35. Rowland, S. (1996). 'Relationships between teaching and research', Teaching in Higher Education 1(1), 7-20.

36. Saaty, T.L. The Analytic Hierarchy Process, McGraw-Hill, New York; 1980.

37. Saaty, T.L. Decision Making with Dependence and Feedback: The Analytic Network Process, RWS Publications, Pittsburgh; 1996.

38. Sarkis J., Sundarraj R.P. Hub location at Digital Equipment Corporation: A comprehensive analysis of qualitative and quantitative factors. European Journal of Operational Research 2002; 137; 336-347.

39. Siegel, D., Waldman, D.A., Atwater, L., Link, A. Toward a model of the effective transfer of scientific knowledge from academicians to practitioners; qualitative evidence from the commercialization of university technologies. J. Eng. Technol. Management 2004; 21; 115-142.

40. Smeby, J.C. (1998). 'Knowledge production and knowledge transmission. The interaction between research and teaching at universities', Teaching in Higher Education 3(1), 5-20.

41. Stephan, P. E. Educational Implications of University/Industry Technology Transfer. Journal of Technology Transfer 2001; 26; 199-205.

42. Vaidya, O.S., Kumar, S. Analytic Hierarchy Process: An overview of applications. European Journal of Operational Research 2006; 169; 1-29.

43. $\mathrm{Xu}, \mathrm{Z}$. On consistency of the weighted geometric mean complex judgement matrix in AHP. European Journal of Operational Research 2000; 126; 683-687.

44. Yurdakul, M. AHP as a strategic decision-making tool to justify machine tool selection. Journal of Materials Processing Technology 2004; 146; 365-376. 


\section{ANNEX 1: Questionnaire AHP criteria weighting}

For each pair of criteria please indicate, by highlighting in black, which of the two you consider to be most important and to what extent. Remember that these are criteria to be used in the evaluation of training proposal reports. The criteria must be compared pairwise, by asking to what degree criterion $\mathrm{C}_{\mathrm{i}}$ is better compared with criterion $\mathrm{C}_{\mathrm{j}}$, using the following scale (Saaty's scale):

$\mathrm{Cij}=1$ : criterion $\mathrm{i}$ and criterion $\mathrm{j}$ are considered equally important

$\mathrm{Cij}=3$ : criterion $\mathrm{i}$ is considered weakly more important than criterion $\mathrm{j}$

$\mathrm{Cij}=5$ : criterion $\mathrm{i}$ is considered strongly more important than criterion $\mathrm{j}$

$\mathrm{Cij}=7$ : criterion $\mathrm{i}$ is considered demonstrably or very strongly more important than criterion $\mathrm{j}$

$\mathrm{Cij}=9$ : criterion $\mathrm{i}$ is considered absolutely more important than criterion $\mathrm{j}$

O1: To create and incorporate advanced knowledge at a national and international level

$\mathrm{O} 2$ : To train citizens, professionals and researchers

\begin{tabular}{|l|l|l|l|l|l|l|}
\hline Which objective do you consider more important? & O1 & \multicolumn{4}{|l|}{ O2 } & \multicolumn{4}{|l|}{} \\
\hline To what extent? & 1 & 3 & 5 & 7 & 9 \\
\hline
\end{tabular}

O1: To create and incorporate advanced knowledge at a national and international level

O3: To study and analyse national problems and propose solutions

\begin{tabular}{|l|l|l|l|l|l|l|}
\hline Which objective do you consider more important? & O1 & O3 & \multicolumn{4}{|l|}{} \\
\hline To what extent? & 1 & 3 & 5 & 7 & 9 \\
\hline
\end{tabular}

O1: To create and incorporate advanced knowledge at a national and international level

O4: To benefit the local community with its academic activities

\begin{tabular}{|l|l|l|l|l|l|}
\hline Which objective do you consider more important? & O1 & O4 & \multicolumn{4}{|l|}{} \\
\hline To what extent? & 1 & 3 & 5 & 7 & 9 \\
\hline
\end{tabular}

O1: To create and incorporate advanced knowledge at a national and international level

O5: To participate in national and international organisations

\begin{tabular}{|l|l|l|l|l|l|l|}
\hline Which objective do you consider more important? & O1 & O5 & \multicolumn{4}{|l|}{} \\
\hline To what extent? & 1 & 3 & 5 & 7 & 9 \\
\hline
\end{tabular}

O2: To train citizens, professionals and researchers

O3: To study and analyse national problems and propose solutions

\begin{tabular}{|l|l|l|l|l|l|l|}
\hline Which objective do you consider more important? & O2 & O3 & \multicolumn{4}{|l|}{} \\
\hline To what extent? & 1 & 3 & 5 & 7 & 9 \\
\hline
\end{tabular}


$\mathrm{O} 2$ : To train citizens, professionals and researchers

O4: To benefit the local community with its academic activities

\begin{tabular}{|l|l|l|l|l|l|}
\hline Which objective do you consider more important? & O2 & O4 & \multicolumn{4}{|l|}{} \\
\hline To what extent? & 1 & 3 & 5 & 7 & 9 \\
\hline
\end{tabular}

$\mathrm{O} 2$ : To train citizens, professionals and researchers

O5: To participate in national and international organisations

\begin{tabular}{|l|l|l|l|l|l|}
\hline Which objective do you consider more important? & O2 & \multicolumn{3}{|l|}{ O5 } & \multicolumn{4}{|l|}{$\mid$} \\
\hline To what extent? & 1 & 3 & 5 & 7 & 9 \\
\hline
\end{tabular}

O3: To study and analyse national problems and propose solutions

O4: To benefit the local community with its academic activities

\begin{tabular}{|l|l|l|l|l|l|l|}
\hline Which objective do you consider more important? & O3 & O4 & \multicolumn{4}{|l|}{} \\
\hline To what extent? & 1 & 3 & 5 & 7 & 9 \\
\hline
\end{tabular}

O3: To study and analyse national problems and propose solutions

O5: To participate in national and international organisations

\begin{tabular}{|l|l|l|l|l|l|l|}
\hline Which objective do you consider more important? & O3 & \multicolumn{3}{|l|}{ O5 } & \multicolumn{4}{|l|}{} \\
\hline To what extent? & 1 & 3 & 5 & 7 & 9 \\
\hline
\end{tabular}

O4: To benefit the local community with its academic activities

O5: To participate in national and international organisations

\begin{tabular}{|c|c|c|c|c|c|}
\hline Which objective do you consider more important? & $\mathrm{O} 4$ & O5 & & & \\
\hline To what extent? & 1 & 3 & 5 & 7 & 9 \\
\hline
\end{tabular}

\section{ANNEX 2: Questionnaire ANP criteria weighting}

With respect to "To train citizens, professionals and researchers" for each pair of linkage mechanisms please indicate, by highlighting in black, which of the two you consider to be most influential and to what extent.

Remember that these are criteria to be used in the evaluation of training proposal reports.

The technology transfer mechanism must be compared pairwise, by asking to what degree criterion $\mathrm{C}_{\mathrm{i}}$ is better compared with criterion $\mathrm{C}_{\mathrm{j}}$, using the following scale (Saaty's scale):

$\mathrm{Cij}=1:$ mechanism $\mathrm{i}$ and mechanism $\mathrm{j}$ are considered to be equally influential

$\mathrm{Cij}=3$ : mechanism $\mathrm{i}$ is considered to be slightly more influential than mechanism $\mathrm{j}$

$\mathrm{Cij}=5$ : mechanism $\mathrm{i}$ is considered to be significantly more influential than mechanism $\mathrm{j}$

$\mathrm{Cij}=7$ : mechanism $\mathrm{i}$ is considered to be far more influential (or demonstrably more influential) than mechanism $\mathrm{j}$ 
$\mathrm{Cij}=9$ : mechanism $\mathrm{i}$ is considered to be absolutely more influential than mechanism $\mathrm{j}$

M1: Continuing Training

M2: Academic Services

\begin{tabular}{|l|l|l|l|l|l|}
\hline $\begin{array}{l}\text { With respect to "To train citizens, professionals and researchers" } \\
\text { which mechanism do you consider more influential? }\end{array}$ & M1 & M2 & \multicolumn{4}{|l|}{} \\
\hline To what extent? & 1 & 3 & 5 & 7 & 9 \\
\hline
\end{tabular}

M1: Continuing Training

M3: Practical Work Training

\begin{tabular}{|l|l|l|l|l|l|}
\hline $\begin{array}{l}\text { With respect to "To train citizens, professionals and researchers" } \\
\text { which mechanism do you consider more influential? }\end{array}$ & M1 & \multicolumn{3}{|l|}{ M3 } & \multicolumn{3}{|l|}{} \\
\hline To what extent? & 1 & 3 & 5 & 7 & 9 \\
\hline
\end{tabular}

M1: Continuing Training

M4: Programmes and Megaprojects

\begin{tabular}{|l|l|l|l|l|l|}
\hline $\begin{array}{l}\text { With respect to "To train citizens, professionals and researchers" } \\
\text { which mechanism do you consider more influential? }\end{array}$ & M1 & M4 & \multicolumn{4}{|l|}{} \\
\hline To what extent? & 1 & 3 & 5 & 7 & 9 \\
\hline
\end{tabular}

\section{M2: Academic Services}

M3: Practical Work Training

\begin{tabular}{|l|l|l|l|l|l|}
\hline $\begin{array}{l}\text { With respect to "To train citizens, professionals and researchers" } \\
\text { which mechanism do you consider more influential? }\end{array}$ & M2 & M3 & \multicolumn{4}{|l|}{} \\
\hline To what extent? & 1 & 3 & 5 & 7 & 9 \\
\hline
\end{tabular}

M2: Academic Services

M4: Programmes and Megaprojects

\begin{tabular}{|l|l|l|l|l|l|}
\hline $\begin{array}{l}\text { With respect to "To train citizens, professionals and researchers" } \\
\text { which mechanism do you consider more influential? }\end{array}$ & M2 & M4 & \multicolumn{4}{|l|}{} \\
\hline To what extent? & 1 & 3 & 5 & 7 & 9 \\
\hline
\end{tabular}

M3: Practical Work Training

M4: Programmes and Megaprojects 


\begin{tabular}{|l|l|l|l|l|l|}
\hline $\begin{array}{l}\text { With respect to "To train citizens, professionals and researchers" } \\
\text { which mechanism do you consider more influential? }\end{array}$ & M3 & M4 & \multicolumn{4}{|l|}{} \\
\hline To what extent? & 1 & 3 & 5 & 7 & 9 \\
\hline
\end{tabular}


ANNEX 3: Statistical data about ANP model

Pairwise comparison questions about ANP model

\begin{tabular}{|c|c|c|c|c|}
\hline & & Teaching/Learning & Research & Third Mission \\
\hline With respect to & Question & No. of questions & No. of questions & No. of questions \\
\hline An objective $\mathrm{C}$ & $\begin{array}{l}\text { Given two mechanisms } A \text { and } B \text {, which } \\
\text { has more influence on Objective } C \text { and } \\
\text { to what extent? }\end{array}$ & 24 & 15 & 15 \\
\hline \multirow[t]{5}{*}{ A mechanism C } & $\begin{array}{l}\text { Given Objectives A and B, which does } \\
\text { mechanism C influence more and to } \\
\text { what extent? }\end{array}$ & 24 & 30 & 30 \\
\hline & QUESTIONS PER MISSION & 48 & 45 & 45 \\
\hline & QUESTIONS MISSIONS & \multicolumn{3}{|c|}{138} \\
\hline & $\begin{array}{c}\text { QUESTIONS ABOUT DEPENDENCE } \\
\text { AND FEEDBACK }\end{array}$ & \multicolumn{3}{|c|}{96} \\
\hline & QUESTIONS ABOUT MODEL & \multicolumn{3}{|c|}{234} \\
\hline
\end{tabular}

Pairwise comparison matrices about ANP model

\begin{tabular}{|c|c|c|c|c|}
\hline & & Teaching/Learning & Research & Third Mission \\
\hline With respect to & Question & No. of matrices & No. of matrices & No. of matrices \\
\hline An objective $C$ & $\begin{array}{l}\text { Given two mechanisms } A \text { and } B \text {, which } \\
\text { has more influence on Objective } C \text { and } \\
\text { to what extent? }\end{array}$ & 4 & 5 & 5 \\
\hline \multirow[t]{5}{*}{ A mechanism C } & $\begin{array}{l}\text { Given Objectives A and B, which does } \\
\text { mechanism C influence more and to } \\
\text { what extent? }\end{array}$ & 4 & 3 & 3 \\
\hline & MATRICES PER MISSION & 8 & 8 & 8 \\
\hline & MATRICES MISSIONS & \multicolumn{3}{|c|}{24} \\
\hline & $\begin{array}{l}\text { MATRICES ABOUT DEPENDENCE } \\
\text { AND FEEDBACK }\end{array}$ & \multicolumn{3}{|c|}{30} \\
\hline & MATRICES ABOUT MODEL & \multicolumn{3}{|c|}{54} \\
\hline
\end{tabular}

